\title{
Fattening of Polish Lowland lambs on diets with different energy and protein levels
}

\author{
J. J. Pająk, T. Żebrowska, M. Słowak and Z. Dlugolęcka
}

The Kielanowski Institute of Animal Physiology and Nutrition,

Polish Academy of Sciences

05-110 Jablonna, Poland

(Received 28 Fcbruary 2000; accepted 15 July 2000)

\begin{abstract}
In an experiment conducted on 96 male lambs (3 groups of 32) fattened from 19 to $39 \mathrm{~kg}$ on diets containing various levels of crude protein (16 vs 14\% in DM) and metabolisable energy (12.4 vs 12.7 $\mathrm{MJ} / \mathrm{kg} \mathrm{DM}$ ) no significant differences in daily liveweight gain were noted (272 to $279 \mathrm{~g}$ ). Fced utilisation was similar in all groups. A tendency $(\mathrm{P}>0.05)$ towards somewhat better protein utilisation $(586 \mathrm{vs} 674 \mathrm{~g} / \mathrm{kg}$ ) from isoenergetic rations was observed in lambs fed rations containing $14 \%$ $\mathrm{CP}$ than in those receiving $16 \% \mathrm{CP}$.

Slaughter performance, morphological and chemical composition of the lambs' empty body weight, protein (18.3-19.8\%) and fat (17.6-21.4\%) deposition in empty body gain did not differ significantly among groups.

Differentiating the level of protein (103-163 $\mathrm{g} / \mathrm{kg}$ DM) in concentrates used to feed suckling lambs had no effect on liveweight gain during fattening (262-288 $\mathrm{g}$ daily).
\end{abstract}

KEY WORDS: Polish Lowland lambs, protein level, rape seeds, fattening, body composition, feeding standards

\section{INTRODUCTION}

Manipulation of sheep dicts may affect growth rate and carcass composition. Restricting feed or protein and energy intake can lead to the production of leaner carcasses (Glimp and Snowder, 1989). According to Searle and Griffiths (1976), the composition of weight gain in lambs is approximately the same on all dicts that support rapid growth. Some studies pointed out, that nutritional management such as protein or energy level in the diet has little influence on sheep body composition (Beauchemin et al., 1995). 
Polish Lowland male lambs (Pająk et al., 1993, 1994) fed isoenergetic rations containing from 14 to $15 \%$ crude protein (CP) in dry matter (DM) showed liveweight gains during fattening similar to those fed according to IZ standards (1993) diets containing $16-17 \% \mathrm{CP}$. This could have been the result of excess protein in relation to nutritional requirements or a concomitant deficit of energy in the diet.

The litcrature contains few reports about the effect of feeding suckling lambs or of their growth rate in this period on the results of fattening; the results of the existing reports are conflicting. Bray et al. (1990) found no effect of the growth rate of suckling lambs on their postweaning growth rate or carcass fat depth, however, lambs growing slowly had the lightest carcasses at a common age. During fattening, lambs fed before weaning with a concentrate containing about $17 \%$ protein showed slower growth and worse feed utilisation than lambs that had been fed a concentrate containing 12 or $15 \%$ CP in DM (Pająk et al., 1994).

The objective of this study was to determine the effect of the protein and energy levels in diets on fattening performance and protein and fat deposition in fattening lambs that during suckling had been fed concentrates with various protein levels.

\section{MATERIAL AND METHODS}

\section{Animals}

The experiment was conducted on 96 weaned male lambs from twin births that during suckling had been fed meadow hay and concentrates containing from 103 to $162 \mathrm{~g} \mathrm{CP}$ in DM (Pająk et al., 2000).

From cach of four groups numbering 30 suckling male lambs, 24 animals with similar body weights were selected for fattening and allocated by an anag method to 3 subgroups of 8 animals each. Each of these subgroups was assigned to one of the fecding groups during fattening (Table 1): S (standard allowances, IZ, 1993), E (energy-supplemented) and L (low-protein, energy supplemented), each numbering 32 lambs. The animals were maintained 8 per pen on wheat straw with free access to water and salt licks containing trace elements.

\section{Experimental diets}

The diets for lambs in groups $\mathrm{S}$ and $\mathrm{E}$ contained $16 \%$ (IZ, 1993), in group L, 14\% crude protein in DM. The EM content in the diet for group S was $12.4 \mathrm{MJ} / \mathrm{kg} \mathrm{DM}$, in that for groups $\mathrm{E}$ and $\mathrm{L}$ it was increased by $0.3 \mathrm{MJ} / \mathrm{kg} \mathrm{DM}$ by adding whole doublc zero rape seeds (Table 2). Concentrates and hay were given twice daily. Refusals were collected and weighed in the morning before a new ration was given. 
TABLE 1

Experimental design

\begin{tabular}{|c|c|c|c|}
\hline Group at suckling period & \multicolumn{3}{|c|}{ Subgroups at fattening period } \\
\hline $\mathrm{C}$ & $\mathrm{S}$ & $\mathrm{E}$ & $L$ \\
\hline $\mathrm{H}$ & ${ }_{H} S$ & $\mathrm{E}$ & $\mathrm{L}$ \\
\hline $\mathbf{M}$ & ${ }_{M} S$ & ${ }_{M}^{\mathrm{H}} \mathrm{E}$ & $\mathrm{L}$ \\
\hline $\mathrm{L}$ & ${ }_{L}^{\mathrm{S}} \mathrm{S}$ & ${ }_{\mathrm{L}}^{\mathrm{m}} \mathrm{E}$ & ${ }_{L}^{M} L$ \\
\hline Group at fattening period $\rightarrow$ & $S$ & $\mathrm{E}$ & $\mathrm{L}$ \\
\hline Protcin content in the ration, \% DM & 16 & 16 & 14 \\
\hline Metabolisable energy, MJ/DM & 12.4 & 12.7 & 12.7 \\
\hline
\end{tabular}

TABLE 2

Composition and nutritive value of dry matter consumed by lambs

\begin{tabular}{|c|c|c|c|}
\hline \multirow[t]{2}{*}{ Component } & \multicolumn{3}{|c|}{ Group } \\
\hline & $\mathrm{S}$ & $\mathrm{E}$ & $\mathrm{L}$ \\
\hline Concentrate mixture. $\%$ & 81.4 & 80.1 & 81.2 \\
\hline roljed oats & 47.8 & 47.8 & 67.5 \\
\hline wheat bran & 15.4 & 14.3 & 8.6 \\
\hline ground wheat & 10.2 & 9.5 & 5.7 \\
\hline ground triticale & 10.2 & 9.5 & 5.7 \\
\hline ground field bean & 5.1 & 4.7 & 2.9 \\
\hline soyabean oilmeal & 9.3 & 8.5 & 5.1 \\
\hline whole rape seeds & 0 & 3.7 & 2.5 \\
\hline mincral-vitamin supplement' & 2 & 2 & 2 \\
\hline Meadow hay, $\%$ & 18.6 & 19.9 & 18.8 \\
\hline \multicolumn{4}{|l|}{ In DM intake: } \\
\hline crude protein, $\mathrm{g}$ & 163 & 163 & 144 \\
\hline degradable, $\mathrm{g}$ & 117 & 118 & 105 \\
\hline undegradable, g & 46 & 45 & 39 \\
\hline digested in small intestinc, $\mathrm{g}$ & 38 & 37 & 33 \\
\hline PDIN.g & 106 & 105 & 95 \\
\hline PDIE, g & 100 & 97 & 93 \\
\hline UFV & 0.94 & 0.93 & 0.93 \\
\hline metabolisable energy, $\mathrm{MJ}$ & 12.4 & 12.7 & 12.7 \\
\hline
\end{tabular}

' in \%: calcium carbonate -45 , dicalcium phosphate -25 , commercial mineral-vitamin supplement Polfamix CJ -15 , sodium chloride -15 
The lambs were weighed every two weeks, and the rations were adjusted according to the average body weight of the animals in a given subgroup. Feed intake, utilisation and daily liveweight gain were determined. Feed intake was compared with the requirements given in the IZ (1993) and INRA (1993) standards.

\section{Slaughter analysis}

The morphological and chemical composition of the cmpty body, protein and fat deposition in empty body gain were determined on 4 representative lambs from subgroup ${ }_{\mathrm{H}} \mathrm{S},{ }_{\mathrm{H}} \mathrm{E}$ and $\mathrm{H}_{\mathrm{H}} \mathrm{L}$ (Table 1) slaughtered at the end of fattening. Each of these lambs in suckling period had been fed with a concentrate containing $16 \%$ crude protein in DM according to IZ standards (1993). Slaughter analysis was carried out as described by Pająk et al. (1992) with modification of separable fat preparation for analysis (Pająk et al., 1993). The initial body composition of lambs was estimated by regression analysis using equations developed from the slaughter data of the initial slaughter groups (Pajak et al., 1999).

\section{Analysis}

The chemical composition of fecds and cmpty body of lambs was detcrmined according to AOAC methods (1990). Protein degradation in the rumen was determined according to Mehrez and Ørskov (1977) on three cows fitted with cannulas to the rumen and duodenum. Effective rumen protein degradation at $\mathrm{k}_{0.16}$ was calculated according to Ørskov and McDonald (1979). Ileal digestibility of rumen undegraded protein was determined according to Hvelplund et al. (1992) using the mobile bag method. The PDIN and PDIE contents were calculated according to INRA (1993) on the basis of the determined ruminal protein degradation cocfficients and ileal digestibility of rumen undegraded protein. Metabolisable energy was calculated using the MAFF equation (1975). Maintenance requirements were calculated assuming $418 \mathrm{~kJ} \mathrm{ME} / \mathrm{kg}^{0.75}$ (Theriez et al., 1982). The energy values of deposited protein $(22.5 \mathrm{~kJ} / \mathrm{g})$ and fat $(39.4 \mathrm{~kJ} / \mathrm{g})$ were taken from Paladines et al. (1964).

\section{Statistical analysis}

The results were subjected to one-way analysis of variance. The significance of differences between means was tested with the Tukcy least significance difference test. All calculations were performed using Statgraphics ${ }^{\text {ki }}$ Plus, ver. 7.0 (1993) software. 


\section{RESULTS}

The crude protein intake of animals in group $\mathrm{L}$ was about $12 \%$ less than in the remaining groups (Table 2 ). The ileal digestible protein intake in group $\mathrm{L}$ was nearly $13 \%$, and in group E, nearly $3 \%$ less than in group S. The PDI content in the $\mathrm{DM}$ of diets $\mathrm{E}$ and $\mathrm{L}$ was smaller than in diet $\mathrm{S}$ by 3 and $7 \%$, respectively.

The value of UFV of all consumed rations was similar. The energy to protein ratio equaled $76 ; 78$ and $88 \mathrm{~kJ} \mathrm{ME} / \mathrm{g} \mathrm{CP}$ in the rations consumed by lambs in groups $\mathrm{S}, \mathrm{E}$ and $\mathrm{L}$, respectively. DM consumption per $\mathrm{kg}$ metabolic body weight $\left(\mathrm{W}^{0.75}\right)$ did not differ and equaled: $88-90 \mathrm{~g} / \mathrm{kg}^{0.75}$ in groups $\mathrm{S}$ and $\mathrm{E}$ and $87 \mathrm{~g} / \mathrm{kg}^{0.75}$ in group $\mathrm{L}$.

The consumed feeds covered from 90 to $93 \%$ of DM requirements according to IZ standards (1993) for lambs gaining $250 \mathrm{~g}$ daily, while coverage of energy requirements was $2-4 \%$ lower (Table 3 ). The nutritional value of the consumed diets according to the INRA system (1993) was $98-102 \%$ of energy requirements, PDI consumption exceeded the requirements of male lambs gaining $250 \mathrm{~g}$ day daily by $8 \%$ in group $L$ to $13-15 \%$ in the remaining groups.

The daily liveweight gains of lambs ( 272 to $279 \mathrm{~g}$ ), duration of fattening (76 to 78 days), DM utilisation (4.1 to $4.2 \mathrm{~kg} / \mathrm{kg}$ body weight gain), and energy utilisation did not depend on the type of diet. In the lambs from group $\mathrm{L}$ a tendency was seen towards somewhat better $(\mathrm{P}>0.05) \mathrm{PDI}$ and crude protein utilisation than in the other groups (Table 4).

No significant differences were found in most of the analyzed slaughter performance indicators among groups (Table 5). Lowering the protein content of the

TABLE 3

The nutritive value of rations in comparison with recommended allowances by IZ and INRA standards!

\begin{tabular}{lccc}
\hline Intake as per cent of requirement & \multicolumn{3}{c}{ Group } \\
\cline { 2 - 4 } & $\mathrm{S}$ & $\mathrm{E}$ & $\mathrm{L}$ \\
\hline IZ (1993) standards & & & \\
dry matter & 91 & 93 & 90 \\
crude protein & 95 & 96 & 83 \\
net cnergy & 87 & 91 & 87 \\
& & & \\
INRA (1993) standards & & & 110 \\
PDIN ${ }^{2}$ & 119 & 125 & 108 \\
PDIE & 113 & 115 & 99 \\
UFV & 98 & 102 & \\
\hline
\end{tabular}

' male gained 250 g/day, moderate growth potential

${ }^{2}$ as per cent of PDI requirement 
TABLE 4

Fattening performance - body weight, liveweight gain and feed utilisation of fattening lambs

\begin{tabular}{|c|c|c|c|c|}
\hline \multirow[t]{2}{*}{ Indices } & \multicolumn{3}{|c|}{ Group } & \multirow{2}{*}{ SEM } \\
\hline & $\mathrm{S}$ & $\mathrm{E}$ & $\mathrm{L}$ & \\
\hline \multicolumn{5}{|l|}{ Body weight, kg } \\
\hline initial & 18.9 & 18.9 & 18.9 & $0.56^{\wedge \mathrm{SS}}$ \\
\hline final & 39.2 & 39.5 & 39.1 & $0.32^{\mathrm{Ns}}$ \\
\hline Daily liveweight gain, g & 272 & 279 & 278 & $8.7^{\mathrm{NS}}$ \\
\hline Fattening period, days & 78 & 76 & 76 & $3.7^{\mathrm{NS}}$ \\
\hline \multicolumn{5}{|l|}{ Feed intake/kg gain } \\
\hline dry matter, $\mathrm{kg}$ & 4.23 & 4.14 & 4.07 & $0.225^{\mathrm{Ns}}$ \\
\hline crude protein, $\mathrm{g}$ & 692 & 674 & 586 & $36.8^{\mathrm{NS}}$ \\
\hline metabolisable energy, MJ & 52.7 & 52.4 & 51.5 & $2.85^{\mathrm{NS}}$ \\
\hline UFV & 3.97 & 3.87 & 3.78 & $0.214^{\mathrm{NS}}$ \\
\hline PDIN, g & 449 & 434 & 388 & $24.0^{\mathrm{NS}}$ \\
\hline PDIE, $\mathrm{g}$ & 425 & 402 & 379 & $22.5^{\mathrm{NS}}$ \\
\hline Rearing + fattening, days & 170 & 167 & 167 & $3.6^{\mathrm{NS}}$ \\
\hline
\end{tabular}

TABLE 5

Slaughter performance of fattening lambs

\begin{tabular}{|c|c|c|c|c|}
\hline \multirow[t]{2}{*}{ Indices } & \multicolumn{3}{|c|}{ Group } & \multirow{2}{*}{ SEM } \\
\hline & $\mathrm{S}$ & $\mathrm{E}$ & I. & \\
\hline $\mathrm{n}$ & 4 & 4 & 4 & \\
\hline Initial body weight, $\mathrm{kg}$ & 19.2 & 18.3 & 19.1 & $0.93^{\mathrm{Ns}}$ \\
\hline Final body weight, $\mathrm{kg}$ & 39.4 & 40.9 & 39.4 & $0.77^{\mathrm{Ns}}$ \\
\hline greasy wool, g & 1100 & 1025 & 1150 & $90.9^{N S}$ \\
\hline Days of fattening & $74^{4}$ & $84^{\mathrm{b}}$ & $77^{\text {th }}$ & $3.0^{P<0.05}$ \\
\hline Daily liveweight gain, $g$ & 276 & 267 & 266 & $8.3^{\mathrm{NS}}$ \\
\hline Daily wool gain, g & 15.2 & 12.1 & 15.1 & $1.50^{\mathrm{Ns}}$ \\
\hline Empty body weight & & & & \\
\hline initial. kg & 16.2 & 15.5 & 16.1 & $\begin{array}{l}0.75^{\mathrm{NS}} \\
0.47^{\mathrm{Pe}(0.01}\end{array}$ \\
\hline $\begin{array}{l}\text { final, } \mathrm{kg} \\
\text { Daily } \mathrm{cmnty} \text { body gain, }\end{array}$ & $33.0^{\mathrm{ABd}}$ & $34.1^{\text {Aa }}$ & $31.1^{\mathrm{Bn}}$ & $73^{\mathrm{P}<0.0 \mathrm{~s}}$ \\
\hline Daily empty body gain, $\mathrm{g}$ & $229^{4}$ & $219^{\text {in }}$ & $196^{b}$ & \\
\hline Cold carcas, $\mathrm{kg}$ & $17.3^{3}$ & $18.0^{n}$ & $16.2^{\mathrm{h}}$ & $0.33^{\mathrm{P}<0.05}$ \\
\hline lean, $\%$ & 55.4 & 53.0 & 53.1 & $0.86^{\mathrm{NS}}$ \\
\hline separable fat, $\%$ & 17.1 & 19.8 & 19.5 & $0.92^{\mathrm{NS}}$ \\
\hline connected tissue, $\%$ & 7.2 & 7.2 & 7.2 & $0.50^{\mathrm{NS}}$ \\
\hline bones, $\%$ & 20.3 & 20.0 & 20.2 & $0.43^{\mathrm{NS}}$ \\
\hline fat + connected tissue, $\%$ & $24.3^{a}$ & $27.0^{\mathrm{h}}$ & $26.7^{\mathrm{th}}$ & $0.78^{p<0.05}$ \\
\hline
\end{tabular}


ration did, however, have an unfavourable effect $(\mathrm{P}<0.05)$ on empty body gain and cold carcass weight, although no differences were found in daily liveweight gain. At the same slaughter weight in groups $\mathrm{S}$ and $\mathrm{L}$, the carcasses of group $\mathrm{S}$ lambs were $1 \mathrm{~kg}$ heavier than in group L. After slaughter, group L lambs had from 1.5 to $2 \mathrm{~kg}$ more intestinal content $(8.3 \mathrm{~kg})$ than lambs in the remaining groups $(6.4$ to $6.8 \mathrm{~kg}$ ). No significant differences in meat or separable fat were found, although the carcasses of group S lambs contained about $2 \%$ more meat and about $2.5 \%$ less separable fat than the carcasses of lambs from the remaining groups.

The chemical composition of empty body weight and empty body gain did not differ significantly among groups (Table 6). The protein and ether extract contents in empty body weight of group $\mathrm{S}$ and $\mathrm{L}$ lambs were similar despite their diets differing in protein and metabolisable energy levels. Increasing the cnergy content from 12.4 to $12.7 \mathrm{MJ} \mathrm{ME} / \mathrm{kg} \mathrm{DM}$ in the diet for group E caused a nearly $2 \%$ rise $(\mathrm{P}>0.05)$ in the share of either extract in empty body weight and almost $4 \%$ in empty body gain at the expense of a slight decrease in the share of protein in the body and gain.

The applied method of rearing suckling lambs caused a significantly worse $(\mathrm{P}<0.01)$ growth ratc from day 28 to weaning at about 90 days of age of lambs that during suckling had been fed concentrates with the lowest (103 g/ $\mathrm{kg} \mathrm{DM)} \mathrm{CP}$ content (Table 7). These lambs where the lightest at the beginning of fattening, but this had no cffect on the growth rate during fattening in comparison with lambs that had been fed with a higher-protein concentrate mixture (135-162 $\mathrm{g} / \mathrm{kg} \mathrm{DM})$. Feeding during suckling also had no effect on the size of the daily liveweight gain from day 28 of life to a weight of about $40 \mathrm{~kg}$.

TABLE 6

Chemical composition of the empty body

\begin{tabular}{|c|c|c|c|c|}
\hline \multirow[t]{2}{*}{ Indices } & \multicolumn{3}{|c|}{ Group } & \multirow[t]{2}{*}{ SEM } \\
\hline & $S$ & $E$ & $\mathrm{~L}$ & \\
\hline $\mathrm{n}$ & 4 & 4 & 4 & \\
\hline Empty hody weight. $\mathrm{kg}$ & $33.0^{\mathrm{ABa}}$ & 34. $1^{\mathrm{Aa}}$ & $31.1^{\mathrm{Bh}}$ & $0.47^{P<(1) .01}$ \\
\hline dry matter, $\%$ & 38.6 & 39.6 & 39.5 & $0.68^{\mathrm{NS}}$ \\
\hline crude protein, \% & 18.1 & 17.5 & 18.0 & $0.31^{\mathrm{NS}}$ \\
\hline ether extract, \% & 16.3 & 18.1 & 16.8 & $0.68^{\mathrm{NS}}$ \\
\hline crude ash, \% & 3.0 & 3.3 & 3.2 & $0.15^{\wedge \mathrm{S}}$ \\
\hline Empty body gain, $\mathrm{kg}$ & $16.8^{\mathrm{atr}}$ & $18.6^{4}$ & $15.0^{\mathrm{h}}$ & $0.82^{P<0.015}$ \\
\hline \multicolumn{5}{|c|}{ As per cent of empty body gain } \\
\hline dry matter & 42.2 & 44.0 & 44.4 & $1.38^{\mathrm{NS}}$ \\
\hline crude protein & 19.8 & 18.3 & 19.6 & $0.69^{\mathrm{NSS}}$ \\
\hline ether extract & 17.6 & 21.4 & 18.8 & $1.47^{\mathrm{NS}}$ \\
\hline
\end{tabular}


TABLE 7

Fattening performance related to protein level in creep feed during the rearing period

\begin{tabular}{|c|c|c|c|c|c|}
\hline \multirow[t]{2}{*}{ Indices } & \multicolumn{4}{|c|}{ Group in rearing period } & \multirow{2}{*}{ SEM } \\
\hline & $\mathrm{C}$ & $\mathrm{H}$ & $\mathrm{M}$ & $\mathrm{L}$ & \\
\hline $\mathrm{n}$ & 24 & 24 & 24 & 24 & \\
\hline \multicolumn{6}{|l|}{ REARING } \\
\hline \multicolumn{6}{|l|}{ Body weight, $\mathrm{kg}$} \\
\hline at 2 day of age & 4.5 & 4.6 & 4.6 & 4.4 & $0.12^{\mathrm{NS}}$ \\
\hline at 28 day of age & 10.2 & 9.5 & 9.5 & 10.0 & $0.29^{\mathrm{NS}}$ \\
\hline at weaning & $20.1^{\mathrm{A}}$ & $19.2^{\mathrm{AB}}$ & $18.7^{\mathrm{AB}}$ & $17.8^{\mathrm{B}}$ & $0.62^{P(0) 01}$ \\
\hline Days of age at weaning & $93^{\mathrm{A}}$ & $89^{\circ}$ & $93^{\mathrm{A}}$ & $91^{\mathrm{B}}$ & $0.4^{\mathrm{P}<1.01}$ \\
\hline \multicolumn{6}{|l|}{ Daily liveweight gain, g } \\
\hline from 21028 days of age & $217^{a}$ & $187^{\mathrm{b}}$ & $191^{\text {ath }}$ & $215^{\mathrm{ab}}$ & $10.5^{P<0.05}$ \\
\hline from 28 days of age to weaning & $152^{\wedge}$ & $160^{\mathrm{A}}$ & $141^{\mathrm{AB}}$ & $122^{\mathrm{B}}$ & $7.6^{\mathrm{P}<001}$ \\
\hline \multicolumn{6}{|l|}{ FATTENING } \\
\hline \multicolumn{6}{|l|}{ Body weight, $\mathrm{kg}$} \\
\hline initial & $20.1^{A}$ & $19.2^{\mathrm{AB}}$ & $18.7^{\mathrm{AB}}$ & $17.8^{\mathrm{B}}$ & $0.62^{p<t) .01}$ \\
\hline final & 39.4 & 38.7 & 39.6 & 39.4 & $0.37^{\mathrm{NS}}$ \\
\hline Fattening period, days & $69^{:}$ & $79^{\mathrm{ul}}$ & $76^{\text {ah }}$ & $82^{h}$ & $4.2^{P<(1.05}$ \\
\hline Daily liveweight gain. $g$ & 286 & 262 & 288 & 271 & $9.9^{\text {Ns }}$ \\
\hline \multicolumn{6}{|l|}{ REARING + FATTENING } \\
\hline Days of age & 162 & 167 & 169 & 173 & $4 . i^{N S}$ \\
\hline Daily livewcight gain, $\mathrm{g}$ & 216 & 207 & 211 & 204 & $5.4^{\mathrm{NS}}$ \\
\hline
\end{tabular}

\section{DISCUSSION}

The applied experimental factors, increasing the metabolisable energy content and lowering the crude protein level in diets did not significantly affect liveweight gains or feed utilisation by Polish Lowland lambs fattened from 19 to $40 \mathrm{~kg}$ body weight (Table 4). Only a tendency towards somewhat better DM and CP (by $2-3 \%$ ) utilisation was found when the energy level of isonitrogenous diets was increased by $0.3 \mathrm{MJ} / \mathrm{kg}$ DM. Decreasing the protein content of the diet from 16 to $14 \%$ in the DM of isocnergetic diets slightly improved DM utilisation, and CP utilisation per $\mathrm{kg}$ liveweight gain was about $13 \%(\mathrm{P}>0.05)$ smaller.

It is thought that adding fat to sheep diets to increase their energy value may unfavourably affect the activity of rumen bacteria, especially when freely dispersed vegetable oils are added (Pallister and Smithard, 1987; Szumacher-Strabel and Potkański, 1997). This depends, however, on the amount of fat and the form in which it is used. The addition of $4 \%$ rape seed oil in the form of whole seeds, 
a mixture of oil and rape seed oil meal or extruded seeds to rations for adult wethers did not adversely affect fermentation in the rumen or fibre digestibility (Pallister and Smithard, 1987). The growth rate of the lambs that received 0,40 , or $60 \mathrm{~g}$ whole rape seeds during fattening in their daily ration did not differ significantly, however, the animals receiving rape seed had slightly increased meat fat and total blood lipids, however, there were no differences in fatty acid profiles of meat fat between groups (Borowice et al., 1996).

In our experiment, despite the smaller share of rape seeds in the ration than in the studies cited above, somewhat more separable fat, a greater share of ether extract in empty body weight and empty body gain were found in the experimental groups as compared with the controls.

Rape seeds can be a good source of energy for sheep, since their hulls delay release of fat in the rumen thanks to which the amount of unsaturated fatty acids absorbed in the small intestine increases. The results of the expcriments of Borowiec et al. (1996) did not, however, show differences in the proportions of fatty acids in the meat fat of lambs fed diets containing various amounts of rape seeds.

The crude protein content of consumed feeds can affect the growth rate of lambs, but this depends on their age, breed, and proportion of protein to energy in the diet.

The better gains of lambs than in previous experiments (Pająk et al., 1993, 1994) may have been caused by catch-up growth after the protein-sparing fecding during suckling, but it seems that the large share of lambs from young mothers was also important. Pecters et al. (1995) found that lambs of yearling ewes had lower growth rates than other lambs during the suckling period, but higher growth rates during the fattening period; this finding is confirmed by the results of rearing (Pajak et al., 2000) and fattening in the present experiment.

The liveweight gains of Polish Lowland lambs, a breed obtained by crossing primitive local breeds mainly with the Polish Merino and with Kent, and in some regions of Poland to a limited degree also with Leine and Texcl, are larger than those of Merino lambs and equal from 220 to $240 \mathrm{~g}$ (Pajakk et al., 1993; 1994). The lambs of the Polish Merino usually have smaller gains, about 170-190 g (Urbaniak, 1986, 1994, 1995a). Crossbred Polish Lowland sheep of the Żelazna variety (Polish Lowland ewes x Suffolk or Berrichon du Cher rams) were heavier than purebred Polish Lowland lambs from days 28 to 100 of age $(\mathrm{P}<0.05)$, but there was no significant difference between the breed types at birth and 150 days of age (Niżnikowski ct al., 1997).

Andrews and Ørskov (1970) showed that while the growth rate of lambs slaughtered at $27.5 \mathrm{~kg}$ liveweight was greater for those given diets containing 17.5 rather than $15 \% \mathrm{CP}$, there were no differences in growth ratc for lambs receiving 17.5 or $15.0 \%$ protein when they were slaughtered at $40 \mathrm{~kg}$ liveweight, which is related to the decline in their protein requirement with age during fattening. 
Similar growth rates, no differences in feed intake or utilisation were also found, among others, in the fattening of crossbred Suffolk x Scottish Blackface lambs fed 120 or $180 \mathrm{~g} \mathrm{CP} / \mathrm{kg}$ DM (Sinclair et al., 1991), as well as Thracian Fine-Fleceed male lambs given 130-189 g CP/kg DM (Shindarska, 1987). Better production performance was obtained in Polish Merino lambs fed diets containing $12 \mathrm{MJ} \mathrm{ME}$ and $124 \mathrm{~g} \mathrm{CP} / \mathrm{kg}$ DM than with diets containing 93 to $159 \mathrm{~g} \mathrm{CP} / \mathrm{kg}$ DM (Urbaniak, 1986). Chios male lambs fed diets containing $16 \% \mathrm{CP}$ grew faster than those receiving 14 or $18 \% \mathrm{CP} / \mathrm{kg}$ DM (Hadjipanayiotou, 1982).

The lack of differences in daily liveweight gains in lambs fed diets often differing considerably in their protein contents may result from overfecding or the inappropriate composition of the diets. This conclusion is supported, among others, by the observation that urinary $\mathrm{N}$ increased in response to increments of dietary CP concentration (Hadjipanayiotou, 1982), which could have been caused by excess protein when energy requirements were covered or by an energy deficit.

Consumption of crude protein in group $\mathrm{L}$ was $17 \%$, in the remaining groups, $4-5 \%$ lower than given in the $\mathrm{IZ}$ standards (1993) for male lambs gaining $250 \mathrm{~g}$ daily. The net energy deficiency in the consumed diets was $9 \%$ in group $\mathrm{E}$ and $13 \%$ in the others. It may be concluded that the IZ standards (1993) are too high for this type of lamb. Comparison of the nutritional value of the consumed diets with the INRA system requirements (1993) suggests that the protein requirements of the Polish Lowland lamb are 10-15\% higher than given in these standards, and that its encrgy requirements are more or less in agreement with these standards.

The effect of dietary protein level on slaughter performance was not unequivocal and it seems that similarly as in the case of gains, it depends on genetic potential, accurate determination of nutritional requirements, formulation of diets according to them, as well as on the effect of environmental factors.

The share of meat in lamb carcasses in this experiment was $53-55 \%$, in an earlicr study, 55-58\% (Pajak et al., 1993). The carcasses of Polish Lowland lambs in other flocks where they were fattened to $40-43 \mathrm{~kg}$ contained about $62-64 \%$ meat and about $20-17 \%$ separable fat (Gruszecki, 1998) or at a body weight of about $41 \mathrm{~kg}$ they had about $58 \%$ meat and $20 \%$ separable fat (Szymanowski, 1999). The adiposity of the lambs in our experiment (about 15-20\%) was similar or smaller than the studies cited above. There is little data relating to the body composition of Polish Lowland lambs. Moreover, in various regions of the country these sheep differ slightly, different fattening systems are used, hence comparison of our data to others is more difficult.

Increasing dietary $\mathrm{CP}(120 \mathrm{vs} 180 \mathrm{~g} / \mathrm{kg} \mathrm{DM})$ increased cold carcass weight, carcass protein content and fatness class (Sinclair et al., 1991). The CP level (15 vs $18 \% \mathrm{CP}$ in DM) and protein degradability had little effect on growth and carcass characteristics. In addition, supplemental undegradable protein is not required when diets are formulated using primarily barlcy and canola meal (Beauchemin et al., 
1995). Carcass fat and protein were not affected by dietary protein ( 15 or $20 \% \mathrm{CP}$ ) between weaning and puberty in ewe lambs (Zhang et al., 1995).

As the protein level increased from 130 to $189 \mathrm{~g} \mathrm{CP} / \mathrm{kg}$ DM of isoenergetic diets, its deposition in the body increased, especially in the initial phase of fattening, that is, from 13 to $25 \mathrm{~kg}$ body weight. Fat deposition also increased as the protein level of the diet rose, especially in the final period of fattening, i.e. from 25 to $40 \mathrm{~kg}$ body weight (Shindarska, 1987). In contrast, the average weight of carcass fat, and kidney plus channel fat in Border Leicester x Blackface wethers of a body weight of $33 \mathrm{~kg}$, fed isoenergetic diets (12.2 MJ EM/kg DM) containing 120 or $148 \mathrm{~g} \mathrm{CP} / \mathrm{kg} \mathrm{DM}$ was significantly smaller when low protein dicts were fed (Coclho ct al., 1986).

In the present experiments we did not find any significant differences in the chemical composition of empty body weight or empty body gain of lambs depending on the protein and energy levels of the diets. Protein source had no effect on the chemical composition of empty body weight of Polish Merino lambs (Urbaniak, 1995a). However, protein deposition was highest in sheep fed on fish meal ( $35.5 \mathrm{~g} /$ day), followed by blood meal, soyabean meal and casein diet (31.7; 30 and $23.7 \mathrm{~g} /$ day, respectively (Urbaniak, 1995a). In this experiment, Polish Lowland lambs deposited about 38 (group L) to $45 \mathrm{~g}$ (group S) protein daily.

In our experiment differentiating the protein level (103-162 g/kg DM) in concentrates for suckling lambs during rearing had no effect on their gains during fattening $(262-288 \mathrm{~g} /$ day $)$.

Lambs fed limited amounts of feed during a preliminary period (of 128 days), in a subsequent expcrimental period ( 90 - days), fed ad libitum had higher rates of liveweight gain, carcass weight and all non-carcass components than lambs fed ad libitum in the preliminary period (Hegarty et al., 1999). At any rate of carcass gain, lambs fed limited amounts of feed in the preliminary period, contained a significantly lower proportion of fat in carcass gain than lambs fed ad libitum in both periods.

Nutritional history may also have modified the effect on carcass composition by changing the partial efficiency of use of available energy for protein deposition without changing the partial energetic efficiency of fat deposition. Lambs fed limited amounts during a preliminary period deposited significantly more carcass tissue per $\mathrm{kg}$ of metabolisable energy available for growth than lambs fed ad libitum in the preliminary period. They deposited more protein/MJ metabolisable energy available for growth, while deposition of carcass fat $/ \mathrm{MJ} \mathrm{ME}$ did not differ between groups (Hegarty et al., 1999).

In groups $\mathrm{S}$ and $\mathrm{E}$ that received $16 \%$ crude protcin in DM, utilisation of metabolisable energy available for growth $\left(\mathrm{k}_{\mathrm{f}}\right)$ was somewhat better $(0.31 ; 0.31$ vs 0.28$)$ than in group $\mathrm{L}$, fed the diet with a $14 \%$ protein content. Urbaniak (1994) found similar $\left(k_{i}-0.27\right.$ to 0.33$)$ utilisation of energy available for growth in Polish Merino lambs. 
In Polish Lowland male lambs the worst energy utilisation, $\mathrm{k}_{\mathrm{f}}=0.27$, was found when the diet containing about $18 \% \mathrm{CP}$ and $62 \mathrm{~kJ}$ metabolisable energy per gram of crude protein was fed, while the best, $\mathrm{k}_{\mathrm{f}}=0.43$ at a ratio of $74 \mathrm{~kJ} / \mathrm{g}$ when the diet the diet containing about 14\% CP (Pająk et al., 1993) was provided.

In later experiments of Urbaniak (1995b), Polish Merino lambs receiving isonitrogenous $(15 \% \mathrm{CP})$ rations containing various sources of protein utilized this energy better (0.42-0.44) (Urbaniak, 1995b), but those that received casein as the main source of nitrogen in the diet had a $k_{f}$ of only 0.20 (Urbaniak, 1995a). No explanation for these differences was found and no dependence between the protein level in the dict or the ratio of energy to protein and the utilisation of metabolisable energy available for growth was found.

\section{CONCLUSIONS}

The gains of lambs that during fattening were fed diets containing 14 or $16 \%$ crude protein in DM are similar regardless of the dietary energy level, and limiting the protein level during rearing does not have a significant effect on fattening performance.

The addition of whole rape sceds in amounts of $2.5-3.7 \%$ concentrate has no significant effect on production performance or body composition of lambs.

The consumption of dry matter by Polish Lowland lambs during fattening is lower than given in the nutritional standards for shecp in the traditional system, it is therefore necessary to revise these requirements.

\section{REFERENCES}

Andrews R.P., Ørskov E.R., 1970. The nutrition of the early weaned lamb. 1. The in1luence of protein concentration and fecding level on rate of gain in body weight. J. Agr. Sci. 75, $1 !-18$

AOAC, 1990. Association of Oflicial Analytical Chemists, Official Methods of Analysis. $15^{\text {th }}$ Edition. Arlington, VA

Beauchemin K.A., McClclland L.A.. Jones S.D.M., Kozub G.C., 1995. Effects of crude protein content, protein degradability and energy concentration of the diet on growth and carcass characteristics of market lambs fed high concentrate diets. Can. J. Anim. Sci. 75, 387-395

Borowiec F., Furgał K.. Kamiński J., 1996. Utilisation of full-fat double low rapeseed in summer fecding of fattened lambs (in Polish). Rośliny Oleiste 17, 529-537

Bray A.R., Moss R.A., Burton R.N., Saville D.J., 1990. Postweaning growth and carcass leanness of lambs that differed in preweaning growth rate. Proc. NZ Soc. Anim. Prod. 50, 287-29]

Coelho J.F.S., Galbraith H., Topps J.H., 1986. Response of wether lambs to implantation with trenbolone acetate combined with oestradiol- 17 beta at two levels of dietary protein. Ann. Zootech. $35,315-327$ 
Glimp H.A.. Snowder G.D., 1989. Production methods to increase lean and reduce fat in lamb: a review. SID Res. J. 5 (3), 18-27

Gruszecki T., 1998. Slaughter value of hybrid lambs from crossing Polish Lowland sheep with meat breed rams (in Polish), Ann. UMCS, Sect. EE, Zoot. 16, 147-154

Hadjipanayiotou M., 1982. Protein levels for Chios lambs given high concentrate diets. Ann. Zootech. 31. 269-278

Hegarty R.S., Neutze S.A., Oddy V.H., 1999. Effects of protein and energy supply on the growth and carcass composition of lambs from differing nutritional historics. J. Agr. Sci. 132, 361-377

Hvelplund T., Weisbjerg M.R., Andersen L.S., 1992. Estimation of the true digestibility of rumen undegraded dietary protein in the small intestine of ruminants by the mobile bag technique. Acta Agr. Scand., Sect. A., Anim. Sci. 42, 34-39

INRA, Ruminant Nutrition. Recommended Allowances and Feed Tables, 1993. E. Jarrige (Editor). Polish Edition, The Kielanowski Institute of Animal Physiołogy and Nutrition. Jabłonna, pp. 406

IZ: Nutrient Requirements of Cattle and Sheep, Traditional System (in Polish), 1993. R. Ryś (Editor). Research Institute of Animal Production. Kraków, pp. 103

MAFF, 1975. Energy Allowances and Feeding System for Ruminants. Techn. Bull. 33, London

Mehrez A.Z., Ørskov E.R., 1977. A study of the artificial fibre bag lechnique for determining the digestibility of feeds in the rumen. J. Agr. Sci. 88, 645-650

Niżnikowski R., Rant W., Sztych D., Czarniak B., 1997. The effect of crossbreeding of ewes of the Polish Lowland sheep of Zelazna varicty with rams of meat breeds on the chosen performance traits of their progeny. Ann. Warsaw Agr. Univ., Anim. Sci. 33, 79-86

Ørskov E.R., McDonald I., 1979. The estimation of protein degradability in the rumen from incubation measurements weighted according to rate of pasagc. J. Agr. Sci. 92, 499-503

Pająk J., Żebrowska T., Żebrowska H., 1992. Protein content in the diet for fattening lambs. 2. The chemical and amino acid composition of the body and utilisation of amino acids apparently absorbed in the small intestine. J. Anim. Feed Sci, 1, 27-36

Pająk J.J., Slowak M., Dakowski P., 1993. Fattening performance of Polish Lowland lambs related to protein level in the diet. J. Anim. Feed Sci. 1, 193-203

Pajak J.J., Żebrowska T., Stowak M., 1994. The effect of the protein level in diets of Polish Lowland lambs on growth and fattening. J. Anim. Feed Sci. 3, 263-27

Pająk J.J., Żebrowska T., Słowak M., Długołęcka Z., 1999. Body composition of Polish Lowland lambs under the conditions of limiting the level of protein during fattening period. Ann. Warsaw Agr. Univ. - SGGW, Anim. Sci. 36, 57-62

Pająk J.J., Żebrowska T., Słowak M., Długolęcka Z., 2000. Rearing suckling Polish Lowland lambs on creep feed with diflerent prolein levels. J. Anim. Feed Sci. 9, 297-308

Paladines O.J., Reid J.T., Bensadoun A., Van Niekerk B.D.H., 1964. Heat of combustion values of the protein and fat in the body and wool of sheep. J. Nutr. 82, 145-149

Pallister S.M., Smithard R.R., 1987. The digestion, by shecp, of diets containing different physical forms of rapeseed. J. Agr. Sci. 109, 459-465

Peeters R., Kox G., van Isterdael J., 1995. Environmental and genetic intluences on growth performance of lambs in different fattening systems. Small Ruminant Res. 18, 57-67

Searle T.W., Griffiths D.A., 1976. The body composition of growing sheep during milk feeding, and the effect on composition of weaning at various body weights. J. Agr. Sci. 86, 483-493

Shindarska Z., 1987. Effect of the encrgy to protein ratio of diets on deposition of fat and protein in the carcass of fattened lambs. 2. Experiments with diets equal in energy with different amounts of protein (in Bulgarian). Zhivol. Nauki 24 (11). 39-44

Sinclair L.A., Galbraith H., Scaife J.R., 1991. Elfect of dietary protein concentration and cimaterol on growth and body composition of entire male lambs. Anim. Fecd Sci. Tech, 34, 181-192 
Statgraphics ${ }^{\Uparrow}$ Plus ver. 7., 1993. Statistical Graphics System by Graphics Corporation

Szumacher-Strabel M., Potkański A., 1997. A note on the effect of rape seed oil in concentrate/hay ration on microbial protein synthesis in sheep. J. Anim. Feed Sci. 6. 499-505

Szymanowski M., 1999. The use of life ultrasonic measurements in estimation of selected slaughter indicators in sheep (in Polish). Prace Mat. Zoot. 54, 65 - 75

Theriez. M.. Villette Y., Castrillo C., 1982. Influence of metabolizable energy content of the diet and of feeding level on lamb performance. IJ. Utilization of metabolizable energy for growth and fattening. Livest. Prod. Sci. 9, 487 - 500

Urbaniak M., 1986. Protein requirement of Merino lambs fattened from 20 to $40 \mathrm{~kg}$ live weight. Rocz. AR Poznań, Rozpr. nauk. No. 161

Urbaniak M., 1994. Effect of dehydrated lucerne on lamb performance and protein and energy deposition in the body. J. Anim. Feed Sci, 3, 191-199

Urbaniak M., 1995a. Effects of blood meal, fish meal, soybcan meal or casein on growth and body composition in lambs. Small Ruminant Res. 18, 213-217

Urbaniak M., 1995b. Bluc lupin seeds in diets for fattening lambs. J. Anim. Feed Sci. 4, 95-106

Zhang J., Grieve D.G., Coomber B.L., 1995. Effects of dietary protein and beta-agonist on growth and fat deposition in prepubertal lambs. Can. J. Anim Sci. 75, 219-224

\section{STRESZCZENIE}

\section{Tucz jagniąt polskiej owcy nizinnej żywionych dawkami o różnej zawartości białka i energii}

W doświadczeniu przeprowadzonym na 96 tryczkach ( 3 grupy po 32) tuczonych od 19 do $39 \mathrm{~kg}$, żywionych dawkami różniącymi się poziomem białka ogólnego (16 vs $14 \%$ w s.m.) i encrgii metaboliczncj (12.4 vs $12.7 \mathrm{MJ} / \mathrm{kg} \mathrm{s.m}$.) nie stwierdzono istotnych różnic w przyrostach (272 do $279 \mathrm{~g}$ ) masy ciała. Wykorzystanie paszy było podobne we wszystkich grupach. Stwierdzono tendencję nieco lepszego $(\mathrm{P}>0.05)$ wykorzystania białka $(586 \mathrm{vs} 674 \mathrm{~g} / \mathrm{kg})$ z dawck izoenergetycznych przez jagnięta otrzymujące w dawce $14 \mathrm{w}$ porównaniu z $16 \%$ b. og. Pobranie s.m. przez. jagniçta bylo o 7-10\% mniejsze niż przewidują Normy IZ.

Wskaźniki ubojowe, skład morfologiczny i chemiczny masy ciała netto jagniąt oraz odłożenie białka (18.3-19.8\%) i thuszczu (17.6-21.4\%) w przyroście masy ciała netto nie różniły się między grupami.

Zróżnicowanic poziomu białka ogólnego (103-163 g/kg s.m.) w mieszankach stosowanych do dokarmiania jagniąt $w$ odchowie przy matkach nie miało wpływu na przyrosty jagniąt w czasie tuczu (262-288 g dziennic). 